\title{
Promoting Professionalism and Academic Librarianship: Observations on the Marketing of the M.L.S.
}

Brian D. Cameron

Systems/Reference Librarian

Ryerson University Library

Cecile Farnum

Communications and Liaison Librarian

Ryerson University Library

\begin{abstract}
Despite the requirement for librarians to hold an MLS or equivalent, many librarians have not sought opportunities to publicize their credentials. In the college and university environment, this is surprising given the importance placed on credentials and advanced degrees. A brief survey of academic library websites reveals that few are using the web to publicize librarian credentials, and as a result, are missing opportunities to promote their expertise and advanced qualifications to their community.
\end{abstract}

Keywords: Marketing, promotion, credentials, degrees, MLS

Librarians have always been eager to market library services and resources to the broader community. The large body of literature published in these areas is a testament to the profession's commitment to these goals. Recently, Daria Decooman published an annotated bibliography on the topic (1-20). It is evident that far more has been published on marketing services than librarians as degreed professionals. In contrast, there is a paucity of literature addressing the need for librarians to market themselves as educated professionals with advanced degrees, despite the fact that the Master of Library Science (or equivalent) has been a requirement for professional librarians for some time.

Since securing faculty status in many academic institutions, librarians (unlike their teaching faculty counterparts) have not embraced the opportunity to promote and publicize their academic credentials. While it is common knowledge that most university faculty have a Ph.D., academic librarians are rarely assumed to have advanced degrees of any kind, including the requisite masters degree in library science. Reasons for this can be attributed to a lack of awareness of the duties and responsibilities of academic librarians compared to faculty. Despite this discrepancy, librarians have rarely seized the opportunity to market their own academic credentials to their patronage, and continue to focus attention on promoting and publicizing the academic value of the Library, rather than the Librarian. 
Lucy Lettis, in her article "Be Proactive; Communicate Your Worth to Management," argues that librarians need to become 'change agents' and enlighten management $(25-27,29)$. This article provides an excellent review of the competencies required, especially to those working in the Special Libraries field. However, Lettis focuses on educating management and not the broader clientele.

In "Visibility: Decloaking 'the Invisible Librarian'," Kathy Dempsey reviews strategies to promote librarians, by means of open houses, newsletters, presentations, etc. In the short "Tout Your Degrees" section, she argues that we need to append our letters after our names (77-81).

Bill Crowley argues that most people are surprised to find that librarians hold masters degrees, and "are unaware that librarians have educational requirements the equivalent of the business world's MBA or social work's MSW" (46). Crowley is advocating on behalf of the public librarian, but his comments can easily be applied to the sphere of the academic library. Kathleen Low asks us to consider when you last saw M.L.S. on a librarian's business card. Other professions, she argues, do not fail to include degrees (882). In response to Low's article, Susan K. Martin and Don Bosseau argue that, without some sort of post-degree accreditation of librarians, like that used by accountants and other professionals, the degree "is not worth the paper it is printed on" (46). *

Given that the Library website is now the primary marketing tool for academic libraries, it is also the logical place for librarians to market their credentials to their patrons. By browsing the Library websites of many Canadian universities, we were hoping to find librarian credentials prominently displayed in directories or profile pages featuring librarians. Although some libraries have included librarian credentials in their directories, it is fair to say that most do not.

Searching for degree statements was accomplished by browsing library staff directories and by using site searches. It appears to be common practice to list staff and librarians several times on a library website. Librarians may be listed alphabetically, by function, team, department, or subject area. As such, it was necessary to browse several lists. In many cases, it proved exceedingly difficult to locate staff listings or a directory and we spent considerable time simply locating the staff directories. In addition, many universities have several libraries, and browsing directories became very time-consuming.

To follow up this preliminary search, we utilized site search functionality, where available, to confirm our conclusions. We searched for M.L.S., MLS, M.L.I.S. and MLIS. Although there are other equivalent masters degrees in the field (i.e. M.I.St., granted by the University of Toronto), adding those terms to the search would not enhance the specificity of the search. 
We also viewed a random selection of academic department websites to determine the prevalence of the listing of degrees on departmental web pages. We found that the degrees were universally available and prominently displayed. Given the requirements for faculty to obtain advanced degrees in their field, this is not surprising. Another trend we noticed was that large numbers of teaching faculty had a personal page with curriculum vitae. While some libraries have also done this, it was a rare occurrence.

In attempting to come to terms with these discrepancies, we considered various explanations. Although anecdotal and possibly stereotypical, we suggest that the tendency for librarians to be modest and reserved may contribute to the lack of promotion of librarian credentials. Furthermore, given the prominent position of faculty in the university environment, librarians may feel less important in the hierarchy of the academy, which may translate as a reluctance to trumpet our advanced degrees.

Unlike other professions with licensing bodies (medical, legal), there is no equivalent mechanism for ensuring professional competency throughout our careers. While there are internal processes for promotion, there is no requirement for continuing education for the purposes of accreditation. There is a considerable breadth of literature which discusses this issue, and which advocates for required continuing education and professional development for librarians. In light of this discussion, we feel this might encourage greater promotion and visibility of librarian degrees.

Finally, we cannot overestimate how unaware many individuals outside the library sphere are of the need for an MLS. In light of this, librarians must be proactive in promoting our credentials to our community in order to demystify librarianship. One way to counter this is developing profile pages for individual librarians similar to faculty pages, with degrees clearly articulated. Business cards are also an excellent opportunity to market advanced degrees, particularly to faculty, administration and students.

The benefits of promotion in terms of professional status, credibility, respect, and acceptance in the academic community are obvious, but opportunities to do so are often missed. We conclude that few libraries have adequately marketed librarians. Teaching faculty are far more successful at promoting their academic credentials, even though it would seem that they have less need to do so, since the qualifications for professors are far better known. Librarians should look for opportunities to educate the public about the qualifications required to become a librarian, and further promote the value our degrees bring to our profession, and to our patronage. 


\section{Works Cited}

Crowley, Bill. "Save Professionalism." Library Journal 130.14 (2005): 46-48.

Decooman, Daria. "Marketing Library Resources: An Annotated Bibliography."

Library Connect, Pamphlet \#8, Supplement to Library Connect Newsletter

3.4 (2005): 1-20.

Dempsey, Kathy. "Visibility; Decloaking 'the Invisible Librarian'." Searcher 10.7 (2002): 77-81.

Lettis, Lucy. "Be Proactive; Communicate Your Worth to Management." Information Outlook 3.1 (1993): 25-27, 29.

Low, Kathleen. "Confessions of an M.L.S. Librarian." American Libraries 25.9 (1994): 882.

Martin, Susan K. and Don L. Bosseau. "An M.L.S. by Any Other Name..." The Journal of Academic Librarianship 21.1 (1995): 46.

* Erratum:

In response to Low's article, Susan K. Martin and Don Bosseau argue that, without some sort of post-degree accreditation of librarians, like that used by accountants and other professionals, the degree "is not worth the paper it is printed on" (46).

Has been replaced with: 
In response to Low's article, Susan K. Martin and Don Bosseau suggest that, without some sort of post-degree accreditation of librarians, like that used by accountants and other professionals, many librarians may feel the degree "is not worth the paper it is printed on" (46). 